Do Migrants Lower Workplace Wages?

Michael White

Alex Bryson

Department of Quantitative Social Science

Working Paper No. 17-03

February 2017 


\section{Disclaimer}

Any opinions expressed here are those of the author(s) and not those of the UCL Institute of Education. Research published in this series may include views on policy, but the institute itself takes no institutional policy positions.

DoQSS Workings Papers often represent preliminary work and are circulated to encourage discussion. Citation of such a paper should account for its provisional character. A revised version may be available directly from the author.

Department of Quantitative Social Science, UCL Institute of Education, University College London, 20 Bedford Way, London WC1H 0AL, UK 


\title{
Do Migrants Lower Workplace Wages?
}

\author{
Michael White ${ }^{1}$ and Alex Bryson ${ }^{2}$
}

\begin{abstract}
Using nationally representative workplace data for Britain we identify the partial correlation between workplace wages and the percentage of migrants employed at a workplace. We find wages are lower in workplaces employing a higher percentage of migrants, but only when those migrants are non-EEA migrants. However, the effects are no longer apparent when we condition on the ethnic complexion of employees at the workplace. Instead, the wage penalty is attached to the percentage of non-white employees, a finding that is consistent with employer discrimination on grounds of race, or lower worker bargaining power when employees are ethnically diverse.
\end{abstract}

JEL codes: J31; J61; J71

Keywords: Migrants; Migration; Ethnicity; Race; Wages, Earnings; Low pay; Discrimination.

Contact Details: Alex Bryson (a.bryson@ucl.ac.uk), University College London, National Institute of Social and Economic Research and Institute for the Study of Labor

\footnotetext{
${ }^{1}$ Policy Studies Institute, University of Westminster

${ }^{2}$ University College London, National Institute of Social and Economic Research and Institute for the Study of Labor
} 


\section{INTRODUCTION}

Like many parts of the EU, Britain has experienced substantial in-migration in the last few decades, in part due to the free movement of labour which constitutes a fundamental part of the Single European Market and, more recently, to the influx of refugees and economic migrants fleeing conflict and disadvantage in Africa, the Middle East and parts of Asia. As a result, the age and ethnic complexion of the British population has been changing. The share of immigrants among working age adults in the UK more than doubled between 1995 and 2014 - from 8\% to 17\% and now stands at over 6.5 million (Wadsworth, 2015). These changes have occasioned political debate regarding immigration policy, the resource implications for the State, and British identity which culminated in the Brexit vote in June 2016's referendum.

The labour market implications of immigration are hotly contested. On the one hand, there is a general recognition that parts of the economy would be unable to function efficiently without substantial reliance on migrant labour. They include sectors as diverse as the National Health Service, fruit picking and construction. ${ }^{3}$ On the other hand, concerns have been expressed about the potential impact immigration may have on unemployment among native-born working age people and ambient wages, particularly at the lower end of the labour market. As we discuss in Section Two, there is little empirical evidence that immigration has had adverse consequences for the employment prospects or wages of native workers in Britain.

We contribute to the literature on migrant wage effects in Britain in two ways. First, in contrast to the current literature which relies exclusively on household survey data, we are able to locate migrants within workplaces, allowing us to examine the links between concentrations of migrants at the workplace and employees' wages. This is important because some of the channels by which migrants may affect wages, such as through worker bargaining power, can only be measured at workplace-level. Second, we can account for other aspects of workplace diversity which might be correlated with the incidence of migrants. In particular, we take

\footnotetext{
${ }^{3}$ Wadsworth (2015) Table 5 provides a breakdown of immigrant workers by industry.
} 
account of the ethnic composition of workplace employees, thus allowing us to distinguish between the wage implications of migrants, on the one hand, and nonwhite workers on the other. This allows us to consider whether any effects of migrants on workplace wages are attributable to migrant status per se, or the ethnic composition of migrants. The latter might be important if, for example, employers chose to discriminate on the grounds of race rather than migrant status.

Throughout we distinguish EEA from non-EEA migrants in recognition of their very different rights to free movement. We identify the partial correlation between workplace wages and the percentage of EEA and non-EEA migrants employed at a workplace. We find wages are lower in workplaces employing a higher percentage of migrants. These effects, although relatively small, are nevertheless statistically significant having accounted for a range of potential confounding factors using various statistical matching techniques to identify counterfactual workplaces. However, the effects are no longer apparent when we also condition on the ethnic complexion of employees at the workplace. Instead, the wage penalty is attached to the percentage of non-white workers, a finding that is consistent with employer discrimination on grounds of race, or lower worker bargaining power when employees are ethnically diverse. A third possibility is that the ethnic composition of the workplace is correlated with other features of the workplace also affecting wages that we do not observe.

The rest of the paper is set out as follows. In Section Two we discuss the theoretical and empirical literatures on migrants and wages. Section Three introduces our data and empirical strategy. Section Four presents results and Section Five concludes.

\section{$2 . \quad$ LITERATURE}

There are many reasons why there might be an association between the employment of migrants and the incidence of low pay at a workplace. First, migrants may possess lower wage-enhancing attributes than native workers, such as qualifications or labour market experience, which are reflected in their ability to procure lower wages. If this was the sole reason for a differential then conditioning 
on the occupational composition of workers, their workplace tenure, and other human capital attributes would close the differential.

Second, migrants may be observationally equivalent to native workers and, as such, may be direct substitutes for native workers, in which case they may be in direct competition with them in the labour market. This may strengthen the bargaining hand of employers in setting lower wages than they might otherwise have done in the absence of migrant competition for jobs. Of course, in the longer run, in an efficient labour market those migrants who were initially low paid may acquire human capital and rise up the earnings distribution, and the dynamic effects of their absorption into the labour market may have positive effects on employment and earnings. However, if one assumes a relatively fixed demand for labour in the short-run, an increase in labour supply through migrants will shift equilibrium wages downwards. ${ }^{4}$

Third, migrants may be unable to procure the market wage merited by their human capital because they face difficulties in using their skills in the host country. This may be because they lack the language skills necessary to take up the profession they had in their native country, the host country fails to recognize the qualifications they possess or requires them to retrain in full or in part, or because they face employer discrimination. Employers may discriminate against migrants by refusing to employ them or, having done so, by paying them lower wages than their skills and experience merit, or lower than the wages they pay similar native workers. This discrimination may be statistical, in the sense that employers make judgments about classes of worker based on observable attributes, such as language or race, it may arise where employers succumb to pressure from customers or co-workers to discriminate, or it may reflect taste-based discrimination in which employers have a preference for native workers which they pursue in their employment practices, even if this comes at the price of failing to recruit or reward the most productive workers. ${ }^{5}$

\footnotetext{
${ }^{4}$ This assumption regarding fixed short-run labour demand is likely to hold following the sluggish recovery of the British economy after the Great Recession (Amossé et al., 2016).

${ }^{5}$ Few studies distinguish between taste-based and statistical discrimination (Guryan and Charles, 2013). In her correspondence test study for Germany Weichselbaumer (2016) shows employer call-back rates to
} 
Fourth, since migration to Britain has been substantial over many years its effects may have important implications for the operation of the labour market as a whole. Migrants may have profound spillover effects on the way the rest of the economy works, so that standard partial equilibrium assumptions regarding labour market "treatments" do not hold. For instance, native workers may respond to increased migrant competition by shifting to other locales or occupations where they do not face the same level of competition. They may even become economically inactive, raising questions as to whether migrants actually increase the potential supply of labour. Employers may, in turn, respond to the withdrawal or decline of labour supply by native workers for a given type of job by seeking migrant workers instead. ${ }^{6}$

Much of the empirical literature on the impacts of immigration on native and migrant workers is from the United States. ${ }^{7}$ Studies for the United States tend to find wage penalties for migrants and little evidence of wage convergence with assimilation (Lazear, 1999; Hu, 2000). The effect of migration on native workers' wages is hotly disputed. Using data from the United States, Canada and Mexico, Aydemir and Borjas $(2007)$ and Borjas $(2003,2006)$ find that migration had a negative and significant impact on earnings of native workers, as predicted by a competitive model of the labour market. Ottaviano and Peri (2012) find significant negative effects of immigration on previous immigrants' earnings using Census data. However, they find only slightly negative effects of new immigration on native workers' wages in the short-run and positive effects in the long-run. In contrast to these studies, Card (1990) examines the effects of a particular in-flow of migrants to a specific labour market, namely the Mariel boatlift in Miami. He finds no impact of this supply shock on local wages and unemployment rates. However, in reappraising the effect of the boatlift Borjas (2015) finds substantial wage effects among low-skilled workers, consistent with the low-skilled migrants substituting for low-skilled natives.

Muslim women wearing headscarves are lower than the employer call-back rates to otherwise identical women, a finding which appears to be consistent with taste-based discrimination.

${ }^{6}$ Our study - like most in the literature - is unable to address the general equilibrium effects that can arise through changes in aggregate labour supply.

${ }^{7}$ One-third of the studies reviewed by Peri (2014) are from the United States. 
Peri's (2014) review of 27 studies concludes "while the literature reports a range of wage effects of immigration, most estimates are small and, on average, essentially zero". Explaining these findings Peri points to important dynamic labour market effects of immigration arguing "native workers' wages have been insulated by differences in skills, adjustments in local demand and technology, production expansion, and specialization of native workers as immigration rises".

Evidence for the United Kingdom is also mixed. Using the United Kingdom Labour Force Survey (LFS) for 2000 to 2007, Clark and Drinkwater (2008) find migrants did worse than native born workers in terms of both employment rates and earnings. Using LFS and General Household Survey (GHS) data for 1973-2007 Manacorda et al. (2012) find immigration has a sizeable negative effect on existing immigrants' earnings but no significant effect on native workers' wages due to imperfect substitution. ${ }^{8}$

As noted by Ruhs and Vargas-Silva (2014) in their review of the literature, the wage effects of immigration will depend on the skills of migrants, the skills of natives, and specific labour market and institutional conditions. As such "research evidence on the labour market effects of immigration is thus always specific to time and place". Judging by the evidence presented above it seems migration has substantial wage and employment effects on earlier migrants but, at least in Britain, there is no clear evidence that immigration has a wider impact on others in the labour market. The implication is that any substitution effect largely occurs within migrants rather than between migrants and native workers.

The empirical literature is dominated by the analysis of household survey data. Because these data are unable to locate migrant and native workers within and across workplaces, it is limited in what it can say about the demand side of the

\footnotetext{
${ }^{8}$ Elsewhere in Europe Boeri et al. (2011) find that migrant workers have lower wages than similar native born workers in Italy and illegal immigrants suffer an even greater wage penalty. At the top end of the labour market Bryson et al. (2014) find there is a migrant premium among professional footballers in Italy, and that the performance of football teams increases with the percentage migrant, indicating that the migrants are superstars drawn from a higher part of the ability distribution, something that they can leverage in wage negotiations.
} 
labour market and the wage setting behaviour of employers. However, a handful of studies do locate migrants within firms. A recent firm-level study for Germany indicated that firms in the trading sector respond to migrant labour supply shocks by adjusting factor quantities rather than factor prices, suggesting wage effects are minimal (Dustmann and Glitz, 2011). ${ }^{9}$ Lewis (2011) finds similar results for manufacturing plants in the United States. Mitaritonna et al. (2016) find a supplydriven increase in the share of highly educated migrant workers in French departments had a positive effect on firms' total factor productivity and higher wages for natives, consistent with positive complementarities and spillover effects from their skills.

To our knowledge, no studies for the UK have used workplace-level data to examine the links between migration and wages. As such, they can say nothing about the potential effects of the employment of migrants on the wages at particular workplaces. The only recent evidence regarding the links between migration and wage setting in Britain indicates that, although the employment of migrant workers had no significant impact on wage cuts or wage freezes in response to the recession and no effect on cuts to non-wage benefits in response to the recession, the probability of a pay freeze or cut for the largest nonmanagerial occupational group in the last pay settlement rose with the proportion of non-EEA nationals employed by the workplace (Bryson and Forth, 2016). Onequarter (26 per cent) of private sector workplaces had instituted a pay freeze or cut for the largest non-managerial group of employees in the last pay settlement. An increase in one percentage point in the number of non-EEA nationals employed at a workplace raised the probability of a wage freeze or cut by roughly 0.4 of a percentage points. The proportion of EEA nationals was not statistically significant. The authors suggest: "One potential explanation for this finding is that a workplace's ability to employ non-EEA nationals reduces the bargaining power of employees at that workplace, thus limiting employees' ability to resist wage freezes or cuts" (Bryson and Forth, 2016: 161).

\footnotetext{
${ }^{9}$ However, the authors find migration does exert downward wage pressure in the non-tradeable sector.
} 
Although, as noted above, employer discrimination may result in wage penalties for migrants, the issue of discrimination has not featured heavily in the literature on migrant wage effects. This is a potentially important oversight. There is a substantial literature concerning wage gaps between native whites and British ethnic minority workers which is suggestive of discrimination (Blackaby et al., 1998; Longhi et al., 2013). Most workers from EEA countries are ethnically 'white' but many of those from non-EEA countries (e.g., from Africa or the Indian subcontinent) are 'black'. The small amount of evidence from Bryson and Forth (2016) suggests the EEA versus non-EEA distinction is potentially important. Since there is likely to be a high correlation between minority ethnic status and non-EEA status in any analysis for Britain, analyses omitting non-white employment will suffer from omitted variable bias with respect to the association between non-EEA migrants and wages. In what follows we incorporate the percentage ethnic minority workers in our model specifications thus removing this bias and permitting estimation of the non-EEA wage effect independent of nonwhite ethnicity.

\section{DATA AND ESTIMATION}

Our data are the 2011 Workplace Employment Relations Study (WERS11), a national sample survey of British workplaces with at least 5 employees (van Wanrooy et al., 2013). The sampling population covered 90 per cent of British employees at the time. Our analyses use the data from personal interviews with 'the most senior manager with responsibility for employment relations, human resources or staff at the workplace' (van Wanrooy et al., 2013: 5). The manager interviews, averaging 90 minutes in length, were completed in 2680 workplaces, with a response rate of 46 per cent. Our analysis is confined to the sub-sample of managers' interviews that provided information on (a) the workplace's distribution of wages, (b) their employment of workers who were not UK citizens and their employment of (black) ethnic minorities, (c) other control variables used in analysis (see below). Relating to (a) there were 194 cases of missing or unreliable data, and a further 232 were unable to reply to (b). With further missing items under (c), the effective sample size, in whole-economy analyses, was between 2029 and 
2101 workplaces. For comparative purposes, some analyses focused on the private sector, with a sample size around 1700 workplaces.

\subsection{Dependent variables}

Managers were asked to provide numbers of employees being paid at wage rates within six bands, as follows: (1) $£ 5.93$ or below ( 55.93 was the national minimum wage in force at the time of the survey); (2) £5.94 to £7.50; (3) £7.51to £10.00; (4) $£ 10.01$ to £13.00; (5) £13.01 to £18.00; (6) £18.01 or above. To assist managers in preparing this information a 'data sheet' was mailed to them in advance of the interview. The numbers provided were summed and the result compared with the reported overall workforce number. Cases where there was a discrepancy of plus or minus 10 per cent or more were discarded (this amounted to 149 cases included in the 194 data losses referred to earlier). Where there was a discrepancy of less than 10 per cent, all the pay band numbers were adjusted by a common factor such that the discrepancy was eliminated (there were 36 such adjustments in all).

Our dependent variables are derived from this information about the workplace wage distribution. To close the distribution, we used $£ 5.00$ as a lower bound for (1) and $£ 30.00$ as an upper bound for (6). We then derived, by the linear interpolation method, (a) the median wage, (b) the lower quartile wage, for each workplace. Our choice of upper bound for band (6) affects 12 per cent of median estimates and 4 per cent of lower quartile estimates. Our choice of lower bound for band (1) affected 4 per cent of median estimates and 9 per cent of lower quartile estimates. Median estimates are less sensitive to the choice of bounds on the distribution than estimates of the mean would be. Variant analyses with different upper and lower bounds indicated that results are not sensitive to this choice.

The estimated median and estimated lower quartile wage are transformed to natural logarithms. Table 1 provides descriptive statistics concerning the dependent variables. Henceforth, we will refer to these outcomes simply as 'lower quartile wage' and 'median wage', omitting 'log of', except in tables. 
Table 1: Descriptive statistics for estimated wage distribution variables ( $($ hour)

\begin{tabular}{|l|l|l|l|}
\hline & Mean & Standard Deviation & Unweighted N \\
\hline lower quartile of wages & 9.62 & 3.48 & 2484 \\
\hline log of lower quartile & 2.205 & 0.336 & 2484 \\
\hline median of wages & 11.90 & 4.71 & 2483 \\
\hline log of median & 2.40 & 0.390 & 2483 \\
\hline
\end{tabular}

We seek to estimate the effect of non-UK citizen employment on the wage distribution parameters. In the data sheet and at interview the manager was first asked 'Of the employees at this workplace, are there any who are non-UK nationals (i.e., do not have British/UK nationality)?' We use this to derive a dummy variable (ANYNONUK) where code "1" identifies a workplace employing non-UK citizens. About 10 per cent of managers gave a 'don't know' reply and these were excluded from our analysis. If the response was 'yes', two further questions were posed: 'How many of the non-UK nationals working here are nationals from the European Economic Area?'; and, 'How many of the non-UK nationals working here are from outside the European Economic Area?'. Definitions of the EEA area were provided to respondents. We convert these numeric answers to percentages of the total employees at the workplace, labelling them respectively EAPC and NEAPC. Later in the data-sheet and interview the manager was also asked 'Of those currently employed here, how many are from a non-white ethnic group?'. Responses were converted into percentages of total employment, and labelled ETHNICPC. The wording and positioning of the questions rendered the ethnic minority question logically independent of the questions about non-UK employment. Table 2 provides descriptive statistics concerning the above explanatory variables. It also shows the substantial correlations among them. 
Table 2: Descriptive statistics and correlations for key explanatory variables

\begin{tabular}{|l|l|l|l|}
\hline & Mean & Standard & Unweighted N \\
\hline \% EEA employees (EAPC) & 5.36 & 14.84 & 2227 \\
\hline \% non-EEA employees (NEAPC) & 2.95 & 8.52 & 2231 \\
\hline \% (black) ethnic employees & 8.30 & 15.52 & 2297 \\
\hline correlations & EAPC & NEAPC & ETHNICPC \\
\hline \% EEA employees (EAPC) & 1.0 & & \\
\hline$\%$ non-EEA employees (NEAPC) & 0.277 & 1.0 & \\
\hline$\%$ (black) ethnic employees & 0.160 & 0.525 & 1.0 \\
\hline
\end{tabular}

\section{3}

Control variables

The set of control variables used in the analysis are incorporated because they are expected to relate both to workplace wages and the employment of non-UK nationals. We account for the composition of the workforce by identifying the percentage of employees who are female; the percentage falling into each of six occupational classifications (routine, operative, sales, personal service, intermediate and higher; the reference category is 'routine', ie. least-skilled, occupations); and the percentage of employees on temporary contracts. These 'compositional' variables can be interpreted as workplace-level counterparts to individual-level human capital variables. Ideally, one would have workforce proportions at different levels of qualification and training, but occupational groups are highly associated with qualification and with skill-level (see Tåhlin 2007 for interpretation of occupational classes in terms of achieved skill). In addition, variables of a 'structural' nature are included in the controls where these may be expected to influence wage parameters. A dummy variable is used to capture the presence of a trade union recognized for bargaining purposes. A continuous variable is logged to identify the number of employees at the workplace, while a four-category variable identifies the total number of employees throughout multisite organizations, with the reference category being single-site organization. Eleven dummy variables identify the region where the workplace is located while twelve industry dummies capture its activities. A final dummy variable identifies foreign-owned firms, as these are likely to use expatriate employees. Further details are provided in Appendix Tables 1 and 2. 
It is not possible to make causal inferences about the effect of migrant workers on workplace wages since we cannot discount the possibility that any association may be driven by omitted variables biasing our estimates. Nor can we discount reverse causality. To remove bias, a textbook solution would be instrumental variables, but a suitable instrument is not available. Instead, we rely on bias reduction through inclusion of a range of exogenous control variables that are informative about the probability of both low wages and of firms' policy toward employment of non-UK nationals. Further, we reason that as the effect of reverse causation bias is to shift estimates away from zero, our point estimates represent an outer bound on the true effect and we remain able to make some inferences within a bounding perspective (Manski, 1995).

The analysis applies an estimation strategy (Imbens and Wooldridge, 2009) that consists of a data matching stage followed by regression on the pre-matched data. From a statistical viewpoint, pre-matching reduces data variation and renders the subsequent regression estimates more precise. The observed variables will be highly informative about the probability of a workplace engaging in the employment of non-UK nationals, hence matching procedures are likely to be effective in terms of covariate balance and variance reduction.

The quasi-treatment variable used in the matching procedures is ANYNONUK. Thus we match the subsample of workplaces having no employment of non-UK nationals with the subsample that has any such employment. In doing so we make the non-treated sample more like the treated sample (or, like the counterfactual case for the treated sample), along a range of variables that are predictive of the workplace wage distribution and workplace policy toward employing non-UK citizen workers.

Matching is pursued in two ways. First, we use entropy balancing (Hainmueller and $\mathrm{Xu}, 2013)$ which computes weights such that there is covariate balance between the treated and non-treated subsamples. For this procedure, we specified balancing on all the control variables described in the preceding section (omitting 
however the dummy for private sector, since we wish to estimate effects for that sector as a comparative case). We balance on the first moment only (though for dummy variables balancing on the mean also results in balance on variance). After the procedure is applied, all covariate means match to within a tolerance of 0.003. The use of this method reflects the emphasis placed in many applied econometric studies on covariate balance as a criterion of successful matching. Entropy balancing provides an analytic assurance of satisfying this criterion.

As an alternative, we apply semi-parametric matching (using STATA's psmatch2 procedure). Here a probit analysis estimates the probability of each observation taking the value " 1 " on the treatment variable, and these 'treatment propensities' are used to identify non-treated cases that are neighbours to each treated case. (We specified that the 5 nearest neighbours to each treated case should be used, as suggested in the methodological study by Frölich et al., 2015.) The difference in weighted means between the treated and matched non-treated groups provides an estimate (under the $\mathrm{CIA}$ ) of the average causal effect of treatment on the treated (ATT) together with standard errors calculated by the Al (Abadie-Imbens) method. From this procedure, we obtain two additional kinds of information not provided by entropy balancing: the estimated effect of each covariate on the probability of having the quasi-treatment (the employment of non-UK nationals), and identification of cases that are not on the common support of the treated and nontreated samples. So, entropy balancing and semi-parametric matching have complementary features. If the two methods (followed by a common regression procedure) return similar estimates, then overall conclusions can be claimed to have constructive validity.

Regressions were carried out using the weights computed either by entropy balancing or by semi-parametric matching. We make the usual OLS assumption of i.i.d. disturbances. We use a robust variance estimator to allow for weighting and for any departures from homoskedasticity. The dependent variables, explanatory variables and control variables are described above. Results are presented for eight OLS analyses: two dependent variables $x$ two matching weights $x$ two variants in the explanatory variable specifications. In variant (1), the explanatory variables were confined to EAPC and NEAPC. In variant (2), ETHNICPC was 
added to the specification. We also conduct variant analyses (a) for the private sector separately, (b) for variations in control specification, so as to assess coefficient stability.

Before turning to our results it is important to note that we are unable to account for endogeneity of the percentage of migrants at the workplace. No plausible instrument is available and ours is a static setting which means we are unable to account for dynamic adjustment processes which, as the literature review makes clear, can be substantial and may attenuate or magnify the effects we identify.

\section{4. $\quad$ RESULTS}

\subsection{Matching Procedures}

Convergence was achieved when undertaking entropy balancing (implying full mean covariate balance to within a small tolerance), whereas propensity score matching reduced mean bias from $15.3 \%$ to $6.1 \%$ (bias reduction of 60 per cent). The probit resulted in a pseudo-R-squared of 0.30 , and full results are provided in Appendix Table 1. The probability of employing non-UK migrants was lower in unionized workplaces, those with a high percentage of female employees, and in some industries (Public Administration, Utilities and Construction all having a significantly lower probability of employing non-UK nationals than workplaces in Manufacturing). The probability of employing non-UK nationals increased with workplace size, the percentage of temporary workers, foreign ownership, in the South East and Scotland, and in Accommodation and Catering. There are 27 offsupport cases, all in the treated group: these are excluded from the subsequent OLS analyses. The off-support cases have propensity scores close to 1 , they are all very large workplaces (more than 1000 employees) and in 25 of the 27 cases they are located in the South East.

\subsection{Regression Results}

The baseline regression results are reported in Table 3. The table has two panels relating to alternative model specifications. The models contain identical covariates with the exception of the ones in the table. Columns 1 and 2 incorporate weights 
based on entropy balancing, while columns 3 and 4 incorporate PSM weights. Results for median wage models are presented in columns 1 and 3 and the lower quartile wage models appear in columns 2 and 4 . Full results including control variables are shown in Appendix Table 2.

In the Model (1) specifications coefficients for the percentage EEA and non-EEA nationals are negative throughout. However, only those for the percentage nonEEA nationals are statistically significant. These results are apparent whichever wage measure is used and whether one weights with entropy balancing or PSM weights. However, although they remain negatively signed, the migrant coefficients fall in size and become statistically non-significant in the Model (2) specifications which incorporate the percentage of ethnic minority employees. ${ }^{10}$ Instead the percentage of non-white ethnic minority employees is negatively and significantly associated with lower workplace wages, regardless of the wage measure and matching weights used.

Table 3: Weighted OLS Estimates for Workplace Wages

\begin{tabular}{|c|c|c|c|c|c|}
\hline \multirow{2}{*}{$\begin{array}{l}\text { Method: } \\
\text { Outcome: }\end{array}$} & \multicolumn{2}{|c|}{ Entropy balancing } & \multicolumn{2}{|c|}{$\begin{array}{l}\text { Semi-parametric } \\
\text { matching }\end{array}$} & \multirow{2}{*}{$\begin{array}{l}\text { No } \\
\text { matching } \\
\text { log } 1^{\text {st }} \\
\text { quartile } \\
\text { wage }\end{array}$} \\
\hline & $\begin{array}{l}\text { log } \\
\text { median } \\
\text { wage }\end{array}$ & $\begin{array}{l}\text { log } 1 s t \\
q u a r t i l e \\
\text { wage }\end{array}$ & $\begin{array}{l}\text { log } \\
\text { median } \\
\text { wage }\end{array}$ & $\begin{array}{l}\text { log } 1 s t \\
\text { quartile } \\
\text { wage }\end{array}$ & \\
\hline \multicolumn{6}{|c|}{ Model Specification (1): } \\
\hline$\%$ EEA & $\begin{array}{l}-0.00057 \\
(1.39)\end{array}$ & $\begin{array}{l}-0.00085 \\
(2.08)\end{array}$ & $\begin{array}{l}-0.00052 \\
(1.31)\end{array}$ & $\begin{array}{l}-0.00070 \\
(1.80)\end{array}$ & $\begin{array}{l}-0.0067 \\
(1.81)\end{array}$ \\
\hline$\%$ Non-EEA & $\begin{array}{l}-0.0023 \\
(3.08)\end{array}$ & $\begin{array}{l}-0.0023 \\
(3.17)\end{array}$ & $\begin{array}{l}-0.0017 \\
(2.45)\end{array}$ & $\begin{array}{l}-0.0018 \\
(2.63)\end{array}$ & $\begin{array}{l}-0.0020 \\
(3.21)\end{array}$ \\
\hline $\mathrm{N}$ & 2086 & 2087 & 1772 & 1761 & 2087 \\
\hline R-squared & 0.710 & 0.678 & 0.710 & 0.672 & 0.623 \\
\hline \multicolumn{6}{|c|}{ Model Specification (2): } \\
\hline$\%$ EEA & $\begin{array}{l}-0.00049 \\
(1.28)\end{array}$ & $\begin{array}{l}-0.00074 \\
(1.84)\end{array}$ & $\begin{array}{l}-0.00041 \\
(1.09)\end{array}$ & $\begin{array}{l}-0.00057 \\
(1.50)\end{array}$ & $\begin{array}{l}-0.00075 \\
(1.94)\end{array}$ \\
\hline
\end{tabular}

\footnotetext{
${ }^{10}$ The pattern and statistical significance of coefficients in model (1) remain very similar if the model is run on the smaller sample which excludes workplaces with missing data on the percentage ethnic minority employees.
} 


\begin{tabular}{|l|l|l|l|l|l|}
\hline \% Non-EEA & -0.00028 & -0.00034 & -0.0001 & -0.00032 & -0.00064 \\
& $(0.41)$ & $(0.51)$ & $(0.15)$ & $(0.46)$ & $(0.90)$ \\
\hline \% Ethnic minority & -0.0018 & -0.0017 & -0.0015 & -0.0013 & -0.0012 \\
& $(3.31)$ & $(2.82)$ & $(2.86)$ & $(2.26)$ & $(2.40)$ \\
\hline $\mathrm{N}$ & 1976 & 1977 & 1672 & 1660 & 1977 \\
\hline R-squared & 0.720 & 0.674 & 0.719 & 0.669 & 0.617 \\
\hline
\end{tabular}

Notes: (1) Cells report estimates with $|t|$ in parentheses. All analyses use a robust variance estimator. All have full controls, as shown in Appendix Table 2. (2) For the entropy balancing analyses, weights are computed so as to maximize mean covariate balance. For semi-parametric matching, weights are computed for the 'control' sample so as to construct counterparts to each case in the 'treated' sample. For the 'no matching' analyses shown in the right hand column, inverse probability sampling weights are applied in the customary manner.

The rightmost column of Table 3 shows the log lower quartile wage estimates obtained when no pre-matching is performed, i.e. from survey regressions with inverse probability sampling weights. ${ }^{11}$ The estimates are similar to those obtained with the pre-matching procedures, both in magnitude and significance. The results appear robust to choice of weighting method. However, we prefer the estimates which use pre-matching because this leads to a significant gain in variance explained, as indicated by the larger r-squared statistics, underscoring the fact that matching helps tackle unexplained variance.

To judge the practical significance of the findings so far, it is helpful to consider what they indicate about wages in the case of a workplace where 10 per cent of its workforce consists of non-UK-citizen or non-white ethnic minority employees. In doing so it is sensible to ignore estimates that are not significant at least at the 10 per cent level. If we follow model (1), i.e. ignore the overlap of immigrant labour with ethnic minority labour, we find that 10 per cent of workplace labour drawn from EEA countries generates a fall in lower quartile wages of 0.7 per cent (PSM) or 0.85 per cent (entropy balancing). If 10 per cent of labour is drawn from non-EEA countries, this implies a larger fall in the workplace lower quartile wage, namely 1.9 per cent (PSM) or 2.3 per cent (entropy balancing). Non-EEA labour of this magnitude also occasions similar falls in the median wage, 1.8 per cent (PSM) or

\footnotetext{
${ }^{11}$ The results for the log median wage are very similar and are available from the authors on request.
} 
2.3 per cent (entropy balancing). Table 4 shows the monetary implications of these percentage effects.

The practical significance of migrants for wages also depends on how many workplaces have substantial percentages of employees drawn from migrant groups. Approximately 12 per cent of workplaces (one in eight) have at least 10 per cent of their workforce from EEA countries, and approximately 8 per cent (around one in 12) have at least 10 per cent from non-EEA countries. Forty-four per cent of workplaces (weighted) employed no non-UK labour. From a practical viewpoint, it appears that the impact of EEA labour on workplace wages is both small and thinly spread, while the impact of non-EEA labour on wages is somewhat more appreciable though still more thinly spread. That, however, is ignoring the overlapping presence of ethnic minority workers. Taking account of this, as in model (2), the independent effects of non-EEA labour become statistically indistinguishable from zero, while the effect of EEA labour also shrinks but remains significant at the 10 per cent level in the case of the lower quartile wage with entropy balancing weights, where the estimated effect is a 0.75 per cent reduction in the wage for a 10 per cent increase in employment from the EEA countries, equating to a $£ 2.60$ fall in earnings for a 36 -hour week (2011 values).

It is natural to make a comparison between the coefficient for percentage ethnic minority employment and that for the percentage of female employment, as both groups are assumed to be affected by discrimination. It appears that, under the imposed model, the ethnic minority wage penalty is around three-quarters as large as the female gender penalty (see Appendix Table 2). 
Table 4: Monetary implications of estimated migrant effects under model (1) of Table 3

\begin{tabular}{|l|l|l|l|l|}
\hline \multicolumn{2}{|l|}{ Median wage models } & non-eea $\% \geq 10$ & eea $\% \geq 10$ & non-eea $\% \geq 10$ \\
\hline $\begin{array}{l}\text { entropy } \\
\text { balancing } \\
\text { variant }\end{array}$ & eea $\% \geq 10$ & & & \\
\hline hourly wage & n.s & -27.4 p. & $-8.2 \mathrm{p}$. & $-22.1 \mathrm{p}$. \\
\hline $\begin{array}{l}\text { earnings (36 } \\
\text { hour week) }\end{array}$ & n.s & $-£ 9.85$ & $-£ 2.94$ & $-£ 7.97$ \\
\hline $\begin{array}{l}\text { propensity score } \\
\text { variant }\end{array}$ & & & & \\
\hline hourly wage & n.s & -21.4 p. & $-6.7 \mathrm{p}$. & $-18.3 \mathrm{p}$. \\
\hline $\begin{array}{l}\text { earnings }(36 \\
\text { hour week) }\end{array}$ & n.s. & $-£ 7.71$ & $-£ 2.42$ & $-£ 6.58$ \\
\hline
\end{tabular}

Notes. 2011 monetary values. n.s indicates that the model estimates are non-significant so monetary implication is not distinguishable from zero. For implications of model (2) of Table 3, see text. Subsample analysis for the private sector

We next consider whether the foregoing results hold if we look at the private sector separately. Since the public sector (e.g. NHS) employs substantial numbers of non-UK cititzens, and is possibly more constrained by equal opportunities policies and union monitoring, the wage effects of employing non-UK employees might be sharper in the private sector. Table 5 shows private sector regression estimates for data re-weighted for that sector by the entropy balancing method, which preserves sample size better than propensity score matching. The private sector estimates tend to be somewhat less negative and to have lower significance than in the case of the whole economy estimates of Table 3, except in the case of the ethnic minority variable in model (2) where the results are similar to those of Table 3. We do not show the results using propensity score weights, which are broadly similar. It appears then that the overall estimates have not been depressed by inclusion of the public sector. 
Table 5. Weighted OLS Estimates for Workplace Wages in the Private Sector

\begin{tabular}{|l|l|l|}
\hline Method: & Entropy balancing and OLS & \\
\hline Outcome: & log median wage & log lower quartile wage \\
\hline Model (1) & & \\
\hline$\%$ EEA & $-0.00056,1.24$ & $-0.00068,1.55$ \\
\hline$\%$ Non-EEA & $-0.00126,1.70$ & $-0.00091,1.30$ \\
\hline $\mathrm{N}$ & 1552 & 1553 \\
\hline R-squared & 0.751 & 0.720 \\
\hline Model (2) & & \\
\hline$\%$ EEA & $-0.00068,1.48$ & $-0.00068,1.53$ \\
\hline$\%$ Non-EEA & $0.00114,1.42$ & $0.00118,1.61$ \\
\hline$\%$ Ethnic minority & $-0.00202,3.48$ & $-0.00159,3.15$ \\
\hline N & 1467 & 1468 \\
\hline R-squared & 0.724 & 0.680 \\
\hline Notes: As Tabl $3, q$. &
\end{tabular}

Notes: As Table 3, q.v.

\subsection{Coefficient stability across varying specifications}

Examination of coefficient stability across varying specifications has figured prominently in economists' efforts to assess the robustness of estimates (Altonji et al. 2005). The underlying thought is that if an explanatory variable's effect is insensitive to inclusion of additional controls one has greater confidence that the estimate is not severely biased by omitted variables in the final specification.

Table 6 summarizes estimates (with entropy balancing weights) from three levels of covariate control. The left-side two columns of results show the estimates from 'short' models where all control covariates are omitted. The central two columns represent results from 'intermediate' models that include all 'structural' covariates (ownership, industry, size at both workplace and organization level, region, unionization) while omitting the workforce composition covariates (gender, occupation, and contract-type proportions). The right-side two columns show the estimates under the 'full' model with all controls (i.e., copied across from Table 3). Vertically the table has two panels, corresponding to the lower quartile wage and median wage outcomes.

For the lower quartile models, R-squared is small $(<0.02)$ in the short regressions, but increases by about 0.4 in the intermediate models that control for structural variables, while the full regressions add around a further 0.25 to the R-squareds. Similar results are obtained in the median wage models. 
Table 6: Coefficient stability across variant specifications

\begin{tabular}{|c|c|c|c|c|c|c|}
\hline \multicolumn{7}{|c|}{ Log lower quartile wage; entropy balancing weights } \\
\hline Controls & \multicolumn{2}{|l|}{ None } & \multicolumn{2}{|l|}{ Structural only } & \multicolumn{2}{|c|}{ Full (compositional\& } \\
\hline$\%$ EEA & $\begin{array}{l}-0.0020 \\
(2.87)\end{array}$ & $-0.0018(2.50)$ & $\begin{array}{l}-0,0010 \\
(1.90)\end{array}$ & $\begin{array}{l}-0.0009 \\
(1.69)\end{array}$ & $\begin{array}{l}-0.00085 \\
(2.08)\end{array}$ & $\begin{array}{l}-0.00074 \\
(1.84)\end{array}$ \\
\hline $\begin{array}{l}\text { \% Non- } \\
\text { EEA }\end{array}$ & $-0030(2.33)$ & $-0.0016(1.12)$ & $-0.0027(2.50)$ & $0.0006(0.51)$ & $-0.0023(3.18)$ & $\begin{array}{l}-0.00034 \\
(0.51)\end{array}$ \\
\hline $\begin{array}{l}\text { \% Ethnic } \\
\text { minority }\end{array}$ & omitted & $-0.001(0.80)$ & omitted & $\begin{array}{l}-0.0030 \\
(2.91)\end{array}$ & omitted & $-0.0017(2.82)$ \\
\hline $\begin{array}{l}\mathrm{N}, \mathrm{R}- \\
\text { squared }\end{array}$ & $2087,0.0144$ & $1977,0.0132$ & $2087,0.4460$ & $1977,0.4590$ & $2087,0.678$ & $1977,0.673$ \\
\hline \multicolumn{7}{|c|}{ Log median wage; entropy balancing weights } \\
\hline Controls & \multicolumn{2}{|l|}{ None } & \multicolumn{2}{|l|}{ Structural only } & \multicolumn{2}{|c|}{ Full (compositional\& structural) } \\
\hline$\%$ EEA & $\begin{array}{l}-0.0020 \\
(2.56)\end{array}$ & $-0.0018(2.23)$ & $-0.0007(1.32)$ & $\begin{array}{l}-0.0007 \\
(1.26)\end{array}$ & $-0.00057(139)$ & $\begin{array}{l}-0.00049 \\
(1.28)\end{array}$ \\
\hline $\begin{array}{l}\text { \% Non- } \\
\text { EEA }\end{array}$ & $\begin{array}{l}-0.0036 \\
(2.59)\end{array}$ & $-0.0021(1.22)$ & $\begin{array}{l}-0.0031 \\
(2.73)\end{array}$ & $\begin{array}{l}-0.00007 \\
(0.57)\end{array}$ & $-0.0023(3.08)$ & $\begin{array}{l}-0.00028 \\
(0.41)\end{array}$ \\
\hline $\begin{array}{l}\text { \% Ethnic } \\
\text { minority }\end{array}$ & omitted & $-0.0011(0.76)$ & omitted & $\begin{array}{l}-0.0035 \\
(3.44)\end{array}$ & omitted & $-0.0018(2.82)$ \\
\hline $\begin{array}{l}\text { R- } \\
\text { Squared }\end{array}$ & $2086,0.0136$ & $1976,0.0124$ & 0.4574 & $1976,0.476$ & 0.710 & 0.720 \\
\hline
\end{tabular}

Notes: Cells report estimates with $|t|$ in parentheses. All analyses use a robust variance estimator.

The size of the coefficient on the percentage of EEA nationals falls progressively across these specifications (by amounts varying from $40 \%$ to $70 \%$ in comparisons between short and full models). The coefficient on the percentage of non-EEA nationals is less affected by controls and more affected by the inclusion of the ethnic minority variable. In contrast, the coefficient on the percentage of non-white ethnic origin is relatively small in the short specification but increases substantially with the addition of structural controls in the 'intermediate' specifications, and then loses some of this increase when the compositional controls are added in the full model.

Overall, the negative association between percentage non-white and wages is the most robust to inclusion of additional control variables, whereas the estimates for both EEA and non-EEA percentage employment vary widely across specifications. It is important to include compositional variables to avoid upward bias in the estimated effect of percentage non-white employment, and it is also important to include structural variables to avoid downward bias in the same. Further investigation has established that the critical structural variable is region: when this 
is absent the coefficient on percent ethnic minority employees falls toward zero and becomes non-significant. This probably arises because the London and Southeast region has both the highest wages and the largest proportion of workplaces with substantial ethnic minority employment. When the dummy for the south-east region is absent the ethnic minority wage effect moves towards zero.

\section{Conclusions}

Distinguishing between EEA and non-EEA migrants we identify the partial correlation between workplace wages and the percentage of migrants employed at a workplace. We find wages are lower in workplaces employing a higher percentage of migrants. These effects, although relatively small, are nevertheless statistically significant having accounted for a range of potential confounding factors using various statistical matching techniques to identify counterfactual workplaces. However, the effects are no longer apparent when we condition on the ethnic complexion of employees at the workplace. Instead, the wage penalty is attached to the percentage of non-white workers. Of course, there may be factors we do not observe that affect both the propensity to employ migrant workers and the wages paid at the workplace, in which case these omitted variables may affect the estimates we recover. Nevertheless, the results are robust to various model specifications and to alternative methods of matching workplaces with and without migrant employees.

This finding is consistent with employer discrimination on grounds of race, or lower worker bargaining power when employees are ethnically diverse. Efforts to shed further light on the potential mechanisms by which a high percentage of ethnic minorities is associated with lower workplace wages proved unsuccessful. We examined the extent to which the presence of a recognised trade union and the presence of equal opportunities monitoring of pay rates played a role in the size of the ethnic wage penalty. They did not.

The finding that migrant employees play only a small role in workplace wage setting is in keeping with most of the literature reviewed earlier on the wage effects of immigration in Britain. However, until now, few have estimated such effects in a workplace context and few have considered the role played by ethnicity in such 
differentials. This proves to be important since coefficients on the percentage EEA and non-EEA migrants are sensitive to the inclusion of a control for the percentage ethnic minority employees. Future research should establish whether this result holds across time and, if so, the mechanisms that lay behind the wage gap. 


\section{REFERENCES}

Amossé, T., Bryson, A. and Petit, H. (2016) "How did Workplaces Respond to Recession?", Chapter 7 in Amossé, T., Bryson, A., Forth, J. and Petit, H. (eds.) Comparative Workplace Employment Relations: An Analysis of Britain and France, Palgrave Macmillan, pp. 211-240

Aydemir, A. and Borjas, G. (2007) "Cross-country variation in the impact of international migration: Canada, Mexico and the United States", Journal of the European Economic Association, Vol. 5, 663-708

Blackaby, D. H., Leslie, D. G., Murphy, P. D. and O'Leary, N. C. (1998) “The ethnic wage gap and employment differentials in the 1990s: Evidence for Britain", Economic Letters, 58, 1: 97-103

Boeri, T., De Philippis, M., Patacchini, E. and Pellizzari, M. (2011) "Moving to segregation: evidence from 8 Italian cities", Bocconi University, Milan. Mimeo.

Borjas, G. (1987) "Self-selection and the earnings of immigrants" American Economic Review, vol. 77, 531-553.

Borjas, G. (2003) "The labor demand curve is downward sloping: Re-examining the impact of immigration on the labor market", Quarterly Journal of Economics, vol. $118,1335-1374$.

Borjas, G. (2006) "Native internal migration and the labor market impact of immigration", Journal of Human Resources, vol. 41, 221-258

Borjas, G. (2015) "The Wage Impact of the Marielitos: A Reappraisal", NBER Working Paper \#21588

Bryson, A. and Forth, J. (2016) "The UK's Productivity Puzzle", Chapter 5 in Askenazy, P., Bellmann, L., Bryson, A. and Moreno-Galbis, E. (eds.) The Productivity Puzzle across Europe, Oxford University Press, pp. 129-173

Bryson, A., Rossi, G. and Simmons, R. (2014) "The Migrant Wage Premium in Professional Football: A Superstar Effect?", Kyklos, 67, 1: 12-28

Card, D. (1990) "The impact of the Mariel boatlift on the Miami labor market", Industrial and Labor Relations Review, vol. 43, 245-257

Clark, K. and Drinkwater, S. (2008) "The labour market performance of recent migrants" Oxford Review of Economic Policy, vol. 24, 495-516

Dustmann, C. and Glitz, A. (2011) "How Do Industries and Firms Respond to Changes in Local Labor Supply?", CREAM Discussion Paper \#18/11 
Frölich, M., Huber, M. and Weisenfarth, M. (2015) The Finite Sample Performance of Semi- and Nonparametric Estimators for Treatment Effects and Policy Evaluation, IZA Discussion Paper 8756

Guryan, J. and Charles, K. K. (2013) "Taste-based or Statistical Discrimination: The Economics of Discrimination Returns to Its Roots", The Economic Journal, 123, F417-F432

Hainmueller, J. and Xu, Y. (2013) ebalance: A Stata Package for Entropy Balancing Journal of Statistical Software,54(7) 1-18

Hu, W. (2000) "Immigrant earnings assimilation: Estimates from longitudinal data", American Economic Review: AEA Papers and Proceedings, vol. 90, 368-372

Imbens, G.W. and Wooldridge, J.M. (2009) Recent developments in the econometrics of program evaluation, Journal of Economic Literature, 47(1): 5-86

Lazear, E. (1999) "Culture and language" Journal of Political Economy vol. 107, 95-129.

Lewis, E. (2011) "Immigration, Skill Mix and Capital Skill Complementarity", The Quarterly Journal of Economics, 126, 2: 1029-1069

Longhi, S., Nicoletti, C. and Platt, L. (2013) "Explained and unexplained wage gaps across the main ethno-religious groups in Great Britain", Oxford Economic Papers, 65: $471-493$

Manski, C. (1995) Identification Problems in the Social Sciences, Cambridge, MA: Harvard University Press

Manacorda, M., Manning, A. and Wadsworth, J. (2012) "The impact of immigration on the structure of wages: Theory and evidence from Britain", Journal of the European Economic Association, vol. 10, 120-151

Mitaritonna, C., Orefice, G. and Peri, G. (2016) 'Immigrants and Firms' Outcomes: Evidence from France", NBER Working Paper No. 22852

Ottaviano, G. and Peri, G. (2012) "Rethinking the impact of immigration on wages", Journal of the European Economic Association, Vol. 10, 152-197

Peri, G. (2014) "Do immigrant workers depress the wages of native workers?", IZA World of Labor, 42

Ruhs, M. and Vargas-Silva, C. (2014) The Labour Market Effects of Immigration (Oxford: Migration Observatory Briefing, University of Oxford)

Tählin, M (2007) 'Skills and Wages in European Labour Markets: Structure and Change', in Gallie D (ed.) Employment Regimes and the Quality of Work. Oxford: Oxford University Press: 35-76. 
van Wanrooy, B., Bewley, H., Bryson, A., Forth, J., Freeth, S., Stokes, L. and Wood, S. (2013) Employment Relations in the Shadow of Recession: Findings from the 2011 Workplace Employment Relations Study, Basingstoke: Palgrave Macmillan

Wadsworth, J. (2015) "Immigration and the UK labour market", CEP Paper EA019

Weichselbaumer, D. (2016) "Discrimination against female migrants wearing headscarves", IZA Discussion Paper No. 10217 
Appendix Table 1: Estimates from probit regression on use of non-uk employees

\begin{tabular}{|l|l|l|l|}
\hline & $\mathrm{b}$ & $\mathrm{s} . \mathrm{e}$. & $\mathrm{t}$ \\
\hline union recognized & -0.209 & 0.0939 & -2.23 \\
\hline \% female employees & -0.003 & 0.0016 & -1.73 \\
\hline \% higher occupations & 0.0018 & 0.0020 & 0.90 \\
\hline \% intermediate occupations & -0.0025 & 0.0018 & -1.39 \\
\hline \% sales occuapations & 0.0030 & 0.0021 & 1.41 \\
\hline \% personal service occns. & 0.0013 & 0.0022 & 0.60 \\
\hline \% operative occupations & 0.0006 & 0.0022 & 0.27 \\
\hline \% non-permanent contracts & 0.0028 & 0.0014 & 1.99 \\
\hline Yorkshire & 0.203 & 0.1776 & 1.15 \\
\hline East midlands & 0.282 & 0.1840 & 1.53 \\
\hline East anglia & 0.159 & 0.2048 & 0.78 \\
\hline South east and London & 0.801 & 0.148 & 5.40 \\
\hline South west & 0.238 & 0.1747 & 1.36 \\
\hline West midlands & 0.237 & 0.1781 & 1.33 \\
\hline North west & 0.089 & 0.1637 & 0.54 \\
\hline Wales & 0.073 & 0.196 & 0.37 \\
\hline Scotland & 0.285 & 0.169 & 1.68 \\
\hline Mutli-site Organization with: & & & \\
\hline$<1000$ employees & -0.100 & 0.0876 & -1.15 \\
\hline 1000-9999 employees & 0.085 & 0.0968 & 0.87 \\
\hline 10000-plus employees & -0.158 & 0.105 & -1.50 \\
\hline log employees at workplace & 0.566 & 0.079 & 20.25 \\
\hline utilities & -0.539 & 0.2576 & -2.09 \\
\hline construction & -0.613 & 0.2017 & -3.04 \\
\hline distribution & -0.135 & 0.1636 & -0.82 \\
\hline accomodation/catering & 0.547 & 0.1867 & 2.93 \\
\hline transport/communications & -0.146 & 0.1764 & -0.83 \\
\hline finance & -0.283 & 0.324 & -0.87 \\
\hline business services & 0.122 & 0.1476 & 0.82 \\
\hline central and local government & -1.136 & 0.1869 & -6.08 \\
\hline education & -0.276 & 0.1798 & -1.54 \\
\hline health & 0.0574 & 0.1761 & 0.33 \\
\hline other services & -0.128 & 0.159 & -0.81 \\
\hline foreign ownership & 0.212 & 0.1159 & 1.83 \\
\hline constant & -2.3886 & 0.2566 & -9.31 \\
\hline $\mathrm{N}$ & 2117 & & \\
\hline Log-likelihood & -1023.47 & & \\
\hline Pseudo-Rsq. & 0.3025 & & \\
\hline & & & \\
\hline
\end{tabular}


Appendix Table 2 (a): Estimates from robust regressions showing full results: log lower quartile wage, entropy balancing weights

\begin{tabular}{|c|c|c|c|c|c|c|}
\hline & $\mathrm{b}$ & s.e. & $|t|$ & $\mathrm{b}$ & s.e. & $|t|$ \\
\hline \% eea employees & -0.00085 & 0.00041 & 2.08 & -0.00074 & 0.00040 & 1.84 \\
\hline \% non-eea employees & -0.00230 & 0.00072 & 3.17 & -0.00034 & 0.00068 & 0.50 \\
\hline \% ethnic minority employees & omitted & & & -0.00170 & 0.00060 & 2.82 \\
\hline union recognized & 0.0592 & 0.0251 & 2.36 & 0.0841 & 0.0206 & 4.08 \\
\hline$\%$ female employees & -0.0032 & 0.00059 & 5.44 & -0.0023 & 0.0004 & 5.82 \\
\hline$\%$ higher occupations & 0.0076 & 0.00069 & 10.93 & 0.00768 & 0.00057 & 13.37 \\
\hline$\%$ intermediate occupations & 0.0034 & 0.00051 & 6.68 & 0.0037 & 0.00042 & 8.94 \\
\hline$\%$ sales occupations & 0.00016 & 0.00047 & 0.34 & 0.00086 & 0.00042 & 2.05 \\
\hline \% personal service occns. & -0.00010 & 0.00066 & 0.15 & 0.00023 & 0.00051 & 0.45 \\
\hline$\%$ operative occupations & 0.00007 & 0.00052 & 0.13 & 0.00057 & 0.00049 & 1.18 \\
\hline$\%$ non-permanent contracts & -0.00034 & 0.00028 & 1.21 & -0.00037 & 0.00026 & 1.42 \\
\hline Yorkshire & 0.0320 & 0.0451 & 0.71 & 0.00518 & 0.0343 & 0.15 \\
\hline East midlands & 0.0144 & 0.0338 & 0.43 & -0.0253 & 0.0266 & 0.95 \\
\hline East anglia & 0.0211 & 0.0432 & 0.49 & -0.0042 & 0.0330 & 0.13 \\
\hline South east and London & 0.1919 & 0.0331 & 5.79 & 0.1524 & 0.0273 & 5.57 \\
\hline South west & 0.0427 & 0.0393 & 1.08 & -0.0084 & 0.0336 & 0.25 \\
\hline West midlands & 0.1483 & 0.0516 & 2.87 & 0.0552 & 0.0310 & 1.78 \\
\hline North west & 0.0965 & 0.0372 & 2.59 & 0.0276 & 0.0265 & 1.04 \\
\hline Wales & 0.0261 & 0.0386 & 0.68 & -0.0303 & 0.0328 & 0.92 \\
\hline Scotland & 0.0994 & 0.0366 & 2.71 & 0.0504 & 0.0295 & 1.71 \\
\hline \multicolumn{7}{|l|}{ Mutli-site Organization with: } \\
\hline$<1000$ employees & 0.0233 & 0.0238 & 0.98 & 0.0099 & 0.0198 & 0.50 \\
\hline 1000-9999 employees & 0.0107 & 0.0214 & 0.50 & 0.0191 & 0.0212 & 0.90 \\
\hline 10000-plus employees & 0.0199 & 0.0227 & 0.88 & 0.0127 & 0.0241 & 0.53 \\
\hline log employees at workplace & 0.0295 & 0.0064 & 4.57 & 0.0261 & 0.0066 & 4.02 \\
\hline private sector & -0.0185 & 0.0277 & 0.67 & -0.0199 & 0.0226 & 0.88 \\
\hline utilities & 0.1536 & 0.0430 & 3.57 & 0.1608 & 0.0446 & 3.61 \\
\hline construction & -0.0287 & 0.0484 & 0.59 & -0.0135 & 0.0500 & 0.27 \\
\hline distribution & -0.1035 & 0.0388 & 2.67 & -0.1081 & 0.0382 & 2.83 \\
\hline Accomodation/catering & -0.1948 & 0.0321 & 6.06 & -0.1714 & 0.0344 & 4.98 \\
\hline transport/communications & 0.0977 & 0.0327 & 2.99 & 0.1309 & 0.0313 & 4.19 \\
\hline finance & 0.1218 & 0.0412 & 2.96 & 0.1007 & 0.0464 & 2.17 \\
\hline business services & 0.0444 & 0.0312 & 1.42 & 0.0829 & 0.0302 & 2.74 \\
\hline central and local government & -0.0096 & 0.0429 & 0.22 & -0.0084 & 0.0451 & 0.19 \\
\hline education & -0.1214 & 0.0501 & 2.42 & -0.0878 & 0.0480 & 1.83 \\
\hline health & 0.00009 & 0.0549 & 0.00 & -0.0255 & 0.0387 & 0.66 \\
\hline other services & -0.0757 & 0.0337 & 2.24 & -0.0584 & 0.0330 & 1.77 \\
\hline foreign ownership & 0.0862 & 0.0234 & 3.69 & 0.1047 & 0.0251 & 4.17 \\
\hline constant & 1.8304 & 0.0710 & 25.79 & 1.802 & 0.0502 & 35.91 \\
\hline $\mathrm{N}$ & 2087 & & & 1977 & & \\
\hline R-squared & 0.678 & & & 0.674 & & \\
\hline
\end{tabular}

Reference categories are: routine occupations, North region, single-site organization, manufacturing industry. 
Appendix Table 2 (b): Estimates from robust regressions showing full results: log median wage, entropy balancing weights

\begin{tabular}{|c|c|c|c|c|c|c|}
\hline & $b$ & s.e. & $|t|$ & $\mathrm{b}$ & s.e. & $|t|$ \\
\hline \% eea employees & -0.00057 & 0.00041 & 1.39 & -0.00049 & 0.00038 & 1.28 \\
\hline$\%$ non-eea employees & -0.00230 & 0.00074 & 3.08 & -0.00028 & 0.00067 & 0.41 \\
\hline$\%$ ethnic minority employees & omitted & & & -0.00180 & 0.00054 & 3.31 \\
\hline union recognized & 0.0502 & 0.0276 & 1.81 & 0.0800 & 0.0205 & 3.90 \\
\hline$\%$ female employees & -0.00328 & 0.00066 & 4.95 & -0.0022 & 0.00040 & 5.63 \\
\hline$\%$ higher occupations & 0.00851 & 0.00070 & 12.10 & 0.0090 & 0.00047 & 19,15 \\
\hline$\%$ intermediate occupations & 0.00459 & 0.00058 & 7.94 & 0.0049 & 0.00040 & 12.24 \\
\hline$\%$ sales occupations & 0.00005 & 0.00057 & 0.09 & 0.0011 & 0.00047 & 2.25 \\
\hline$\%$ personal service occns. & -0.00074 & 0.00072 & 1.03 & -0.00016 & 0.00049 & 0.32 \\
\hline$\%$ operative occupations & -0.00005 & 0.00058 & 0.08 & 0.00047 & 0.00054 & 0.87 \\
\hline$\%$ non-permanent contracts & -0.00037 & 0.00035 & 1.06 & -0.00039 & 0.00034 & -1.14 \\
\hline Yorkshire & 0.0599 & 0.0474 & 1.26 & 0.0098 & 0.0321 & 0.31 \\
\hline East midlands & 0.0287 & 0.0423 & 0.68 & -0.0256 & 0.0294 & 0.87 \\
\hline East anglia & 0.0454 & 0.0531 & 0.86 & 0.0027 & 0.0363 & 0.07 \\
\hline South east and London & 0.2063 & 0.0423 & 4.87 & 0.1515 & 0.0266 & 5.70 \\
\hline South west & 0.0653 & 0.0456 & 1.43 & -0.0050 & 0.0342 & 0.15 \\
\hline West midlands & 0.1748 & 0.0631 & 2.77 & 0.0455 & 0.0302 & 1.50 \\
\hline North west & 0.1287 & 0.0427 & 3.02 & 0.0515 & 0.0282 & 1.83 \\
\hline Wales & 0.0628 & 0.0464 & 1.36 & -0.0136 & 0.0352 & 0.39 \\
\hline Scotland & 0.1505 & 0.0435 & 2.64 & 0.0456 & 0.0304 & 1.50 \\
\hline \multicolumn{7}{|l|}{ Mutli-site Organization with: } \\
\hline$<1000$ employees & 0.0340 & 0.0274 & 1.24 & 0.0145 & 0.0234 & 0.62 \\
\hline 1000-9999 employees & 0.0035 & 0.0260 & 0.14 & 0.0222 & 0.0232 & 0.96 \\
\hline 10000-plus employees & -0.0285 & 0.0231 & 1.23 & -0.0323 & 0.0234 & 1.38 \\
\hline log employees at workplace & 0.0365 & 0.0061 & 5.94 & 0.0344 & 0.0056 & 6.13 \\
\hline private sector & -0.0326 & 0.0294 & 1.11 & -0.0254 & 0.0228 & 1.11 \\
\hline utilities & 0.1980 & 0.0421 & 4.70 & 0.1763 & 0.0446 & 3.95 \\
\hline construction & -0.1083 & 0.0559 & 0.33 & -0.0116 & 0.0592 & 0.20 \\
\hline distribution & -0.0623 & 0.0429 & 1.45 & -0.0888 & 0.0400 & 2.22 \\
\hline accomodation/catering & -0.2152 & 0.0357 & 6.03 & -0.1966 & 0.0393 & 5.00 \\
\hline transport/communications & 0.1331 & 0.0354 & 3.76 & 0.1673 & 0.0330 & 5.07 \\
\hline finance & 0.1292 & 0.0420 & 3.08 & 0.0952 & 0.0435 & 2.19 \\
\hline business services & 0.0635 & 0.0327 & 1.94 & 0.1003 & 0.0315 & 3.19 \\
\hline central and local government & 0.0029 & 0.0395 & 0.07 & -0.0049 & 0.0410 & 0.12 \\
\hline education & 0.0145 & 0.0467 & 0.31 & 0.0432 & 0.0398 & 1.09 \\
\hline health & 0.0553 & 0.0600 & 0.92 & 0.0015 & 0.0387 & 0.04 \\
\hline other services & -0.0562 & 0.03509 & 1.60 & -0.0460 & 0.0348 & 1.32 \\
\hline foreign ownership & 0.1017 & 0.0283 & 3.60 & 0.1227 & 0.0293 & 4.19 \\
\hline constant & 1.9017 & 0.0824 & 23.08 & 1.8640 & 0.0528 & 35.30 \\
\hline $\mathrm{N}$ & 2086 & & & 1976 & & \\
\hline R-squared & 0.710 & & & 0.720 & & \\
\hline
\end{tabular}

Reference categories are: routine occupations, North region, single-site organization, manufacturing industry. 